\title{
Cardiovascular outcomes trials with statins in diabetes
}

\author{
FARIHA NAEEM, GERARD MCKAY, MILES FISHER
}

\begin{abstract}
Treatment with statins is one of the most effective ways of reducing cardiovascular events in those with diabetes. Many studies containing thousands of subjects with diabetes have demonstrated that statins reduce cardiovascular events when there is no known cardiovascular disease (primary prevention) and in those with confirmed atherosclerotic disease (secondary prevention). High-dose statins appear to be even more effective in established cardiovascular disease, but at the expense of increased drug side effects. In this paper we review the evidence for the benefits of statins in diabetes. In a second review we will examine the evidence for possible benefits of other lipid-lowering therapies when these are added to background statin therapy in diabetes.

Br J Diabetes 2018;18:7-13
\end{abstract}

Key words: diabetes, hypercholesterolaemia, lipids, statins, cardiovascular disease

\section{Introduction}

Cardiovascular disease (CVD) remains the leading cause of morbidity and mortality in those with diabetes mellitus. Diabetes is an independent risk factor for the development of CVD and the presence of diabetes is a poor prognostic marker in those with CVD. The increasing prevalence of diabetes worldwide and the burden on global healthcare that this represents makes developing strategies to improve cardiovascular outcomes a public health priority.

Most research on improving cardiovascular outcomes by addressing cardiovascular risk factors in diabetes relates to those with type 2 diabetes mellitus (T2DM), characterised by insulin resistance with variable degrees of beta-cell dysfunction, and is typically associated with abnormal lipid profiles, obesity and other features of the metabolic syndrome. ${ }^{1}$ In T2DM the abnormal lipid pattern consists of raised concentrations of triglycerides and low high-density lipoprotein cholesterol (HDL cholesterol) concentrations. Total levels of low density lipoprotein cholesterol (LDL cholesterol) are similar

Department of Diabetes, Endocrinology \& Clinical Pharmacology, Glasgow Royal Infirmary, Glasgow, UK

Address for correspondence: Professor Miles Fisher

Consultant Physician, Department of Diabetes, Endocrinology \& Clinical

Pharmacology, Glasgow Royal Infirmary, 84 Castle Street, Glasgow

G4 OSF, UK

E-mail: miles.fisher@ggc.scot.nhs.uk

https://doi.org/10.15277/bjd.2018.161 to populations without diabetes, but with a greater proportion of small-dense particles which are more atherogenic. By contrast, in type 1 diabetes mellitus (T1DM) that is well controlled, triglyceride levels tend to be lower and HDL cholesterol concentrations are average or even high.?

Observational studies have demonstrated a strong positive relationship between raised LDL cholesterol levels and increasing risk of cardiovascular events. ${ }^{3}$ Lowering LDL cholesterol is thought to slow down the development and progression of atherosclerosis and decrease cardiovascular events. Statins have been in clinical use for 20 years and reduce LDL cholesterol by inhibiting 3-hydroxy-3methylglutaryl (HMG CoA) reductase and decreasing endogenous production of LDL cholesterol in the liver.

This review revisits evidence from key randomised cardiovascular outcomes trials and meta-analyses on the cardiovascular benefits of statins in diabetes. In a future paper we will examine the results of newer studies with other lipid-lowering therapies in people with diabetes, including recent results on the effects of PCSK9 inhibitors in these patients.

\section{Primary prevention trials (Table 1 )}

Studies in subjects with diabetes

Two studies have examined statin use for the primary prevention of CVD exclusively in those with diabetes. The Collaborative Atorvastatin Diabetes Study (CARDS) involved 2,838 subjects aged 40-75 from centres around the UK and Ireland who were randomised to either $10 \mathrm{mg}$ atorvastatin or placebo. ${ }^{4}$ Participants had T2DM with no history of CVD, but had at least one other cardiovascular risk factor. The study was terminated 2 years early because the pre-specified stopping rule for efficacy in reducing cardiovascular events had been achieved. Subjects allocated to atorvastatin had a $37 \%$ significant reduction in the primary endpoint of acute coronary heart disease (CHD) events (myocardial infarction, unstable angina, acute CHD death, resuscitated cardiac arrest), coronary revascularisation or stroke. All-cause mortality was numerically lower in the atorvastatin group but was not statistically significantly reduced.

The Atorvastatin Study for Prevention of CHD Endpoints in Noninsulin-dependent diabetes mellitus (ASPEN) study included 2,410 subjects with T2DM who were also assigned to receive $10 \mathrm{mg}$ atorvastatin or placebo. This international study was originally intended to look at secondary prevention with a follow-up of 4 years; however, due to changing guidelines impairing recruitment, the protocol was changed and a primary prevention cohort were also recruited. ${ }^{5}$ For the primary prevention cohort a significant 30\% reduction in LDL cholesterol levels was observed, but no beneficial 
Table 1 Diabetes results from key primary prevention studies

\begin{tabular}{|c|c|c|c|c|}
\hline $\begin{array}{l}\text { Study } \\
\text { (year of } \\
\text { primary } \\
\text { publication) }\end{array}$ & Comparison & Subjects & $\begin{array}{l}\text { Subjects } \\
\text { with } \\
\text { diabetes (\%) }\end{array}$ & $\begin{array}{l}\text { Diabetes } \\
\text { results }\end{array}$ \\
\hline $\begin{array}{l}\text { CARDS } \\
(2004)\end{array}$ & $\begin{array}{l}\text { Atorvastatin } \\
10 \mathrm{mg} \text { vs } \\
\text { placebo }\end{array}$ & 2,838 & $2,838(100 \%)$ & $\begin{array}{l}\text { Significant } \\
37 \% \\
\text { reduction in } \\
\text { primary } \\
\text { endpoint }\end{array}$ \\
\hline $\begin{array}{l}\text { ASPEN } \\
(2006)\end{array}$ & $\begin{array}{l}\text { Atorvastatin } \\
10 \mathrm{mg} \text { vs } \\
\text { placebo }\end{array}$ & 2,410 & $\begin{array}{l}2,410(100 \%), \\
1,905 \text { primary } \\
\text { prevention }\end{array}$ & $\begin{array}{l}\text { No significant } \\
\text { reduction in } \\
\text { primary } \\
\text { endpoint }\end{array}$ \\
\hline $\begin{array}{l}\text { HPS } \\
(2002)\end{array}$ & $\begin{array}{l}\text { Simvastatin } \\
40 \text { mg vs } \\
\text { placebo }\end{array}$ & 20,536 & $\begin{array}{l}5,963(28 \%), \\
2912 \text { primary } \\
\text { prevention }\end{array}$ & $\begin{array}{l}\text { Significant } \\
33 \% \\
\text { reduction in } \\
\text { defined } \\
\text { endpoint for } \\
\text { subcategories }\end{array}$ \\
\hline $\begin{array}{l}\text { ALLHAT-LLT } \\
(2002)\end{array}$ & $\begin{array}{l}\text { Pravastatin } \\
40 \text { mg vs } \\
\text { usual care }\end{array}$ & 10,355 & $3,638(35 \%)$ & $\begin{array}{l}\text { No significant } \\
\text { reduction in } \\
\text { primary } \\
\text { endpoint }\end{array}$ \\
\hline $\begin{array}{l}\text { ASCOT-LLA } \\
(2003)\end{array}$ & $\begin{array}{l}\text { Atorvastatin } \\
10 \mathrm{mg} \text { vs } \\
\text { placebo }\end{array}$ & 10,305 & $2,532(25 \%)$ & $\begin{array}{l}\text { Significant } \\
23 \% \\
\text { reduction in } \\
\text { major } \\
\text { cardiovascular } \\
\text { events or } \\
\text { procedures }\end{array}$ \\
\hline $\begin{array}{l}\text { MEGA } \\
(2006)\end{array}$ & $\begin{array}{l}\text { Pravastatin } \\
10-20 \mathrm{mg} \\
\text { vs usual care }\end{array}$ & 7,832 & $1,632(21 \%)$ & $\begin{array}{l}\text { Significant } \\
36 \% \\
\text { reduction in } \\
\text { coronary } \\
\text { heart disease } \\
\text { events }\end{array}$ \\
\hline
\end{tabular}

effect was found on the primary outcome which was a composite of cardiovascular death, non-fatal myocardial infarction, non-fatal stroke, recanalisation, coronary artery bypass surgery, resuscitated cardiac arrest and hospitalisation for unstable angina. Similar results were found in the small secondary prevention cohort. There are multiple limitations of this flawed study including the change in the study design, the multiple endpoints, the low risk of events in the primary prevention cohort and the extensive use of non-study lipidlowering therapy in both groups.

\section{Trials including large numbers of subjects with diabetes}

Several studies have investigated statin use for primary prevention with substantial subgroups of subjects with diabetes. The Heart Protection Study (HPS) recruited 20,536 patients with CHD, other occlusive vascular disease or diabetes, and included 5,963 with diabetes. ${ }^{6}$ Simvastatin $40 \mathrm{mg}$ or placebo was given over the course of 5 years. 2,912 of the participants with diabetes had no prior vascular disease (49\%) (primary prevention) and in this subgroup the rate of the defined endpoint for subcategories which was major vascular events (cardiovascular death, non-fatal myocardial infarction, stroke, revascularisation) was reduced significantly from $13 \%$ to $9 \%$ in the group receiving simvastatin. ${ }^{7}$

The Antihypertensive and Lipid-Lowering treatment to prevent Heart Attack Trial (ALLHAT) looked at hypertensive treatment in subjects aged 55 years or older. Within this study the Lipid-Lowering trial component (ALLHAT-LLT) randomised 10,355 subjects, including 3,638 (35\%) with T2DM, to open label pravastatin treatment or usual care. No significant difference was found in all-cause mortality (primary outcome) or CHD outcomes (secondary outcome of fatal CHD, non-fatal myocardial infarction) in the whole study group or in the subgroup with diabetes. ${ }^{8}$ One reason for these negative results may be the relatively high rates of statin use in the usual care group, reaching nearly $25 \%$, as intensive lipid lowering became a routine part of clinical care following the presentation and publication of other statin studies.

The Anglo-Scandinavian Cardiac Outcomes Trial (ASCOT) was primarily aimed at investigating hypertensive treatment in 19,342 hypertensive patients, but half of the study group $(n=10,305)$, including 2,532 with T2DM, were allocated to a lipid sub-study with atorvastatin $10 \mathrm{mg}$ or placebo. ${ }^{9}$ Overall results for the lipid-lowering trial showed a significant reduction in the primary endpoint of nonfatal myocardial infarction and fatal CHD with atorvastatin. No statistically significant reduction in this endpoint was found when looking at the subgroup with diabetes. However, a subsequent prespecified analysis of an expanded composite of total cardiovascular outcomes (major cardiovascular events plus procedures) demonstrated a significant reduction for the subgroup with diabetes. ${ }^{10}$

The Management of Elevated Cholesterol in the Primary Prevention Group of Adult Japanese study (MEGA) recruited 7,832 subjects with dyslipidaemia and assigned them to diet modification only or diet plus open-label low-dose pravastatin (10-20 mg). 1,632 subjects $(21 \%)$ were reported by their physicians to have diabetes at baseline. ${ }^{11}$ Overall, the rate of CHD events (fatal or non-fatal myocardial infarction, angina, revascularisation, sudden cardiac death) was significantly reduced in the pravastatin-treated group compared with diet only. Subgroup analysis did not show significant interaction in any subgroup, including the diagnosis of diabetes or not. A post-hoc analysis looked at the subgroup with diabetes and categorised them according to reductions in LDL cholesterol and increases in $\mathrm{HDL}$ cholesterol. ${ }^{12}$ The greatest reduction in risk of CVD was found where LDL cholesterol decreased more than $15 \%$ and $\mathrm{HDL}$ cholesterol increased by more than $5 \%$. Similar results were reported in those without diabetes.

These large trials have demonstrated a significant cardiovascular benefit in statin use for the primary prevention of CVD in diabetes, mostly in those with T2DM (Table 1).

\section{Secondary prevention trials (Table 2)}

The landmark Scandinavian Simvastatin Survival Study (4S) recruited 4,444 patients with a prior history of CHD and hypercholesterolaemia who were randomised to treatment with $20-40 \mathrm{mg}$ simvastatin or placebo. ${ }^{13}$ Over a median duration of 5.4 years of follow-up, those randomised to simvastatin had a significant reduction in all-cause mortality and major CHD events, and this included 
Table 2 Diabetes results from key secondary prevention studies

\begin{tabular}{|c|c|c|c|c|}
\hline $\begin{array}{l}\text { Study } \\
\text { (year of } \\
\text { primary } \\
\text { publication) }\end{array}$ & $\begin{array}{l}\text { Comparison } \\
\text { ) }\end{array}$ & Subjects & $\begin{array}{l}\text { Subjects } \\
\text { with } \\
\text { diabetes (\%) }\end{array}$ & $\begin{array}{l}\text { Diabetes } \\
\text { results }\end{array}$ \\
\hline $\begin{array}{l}4 S \\
(1994)\end{array}$ & $\begin{array}{l}\text { Simvastatin } \\
20-40 \mathrm{mg} \\
\text { vs placebo }\end{array}$ & 4,444 & $\begin{array}{l}202(5 \%) \\
483(11 \%)\end{array}$ & $\begin{array}{l}\text { No significant } \\
\text { reduction in } \\
\text { total } \\
\text { mortality, } \\
\text { significant } \\
55 \% \\
\text { reduction in } \\
\text { major } \\
\text { coronary events }\end{array}$ \\
\hline $\begin{array}{l}\text { CARE } \\
(1996)\end{array}$ & $\begin{array}{l}\text { Pravastatin } \\
40 \mathrm{mg} \text { vs } \\
\text { placebo }\end{array}$ & 4,159 & $586(14 \%)$ & $\begin{array}{l}\text { No significant } \\
\text { reduction in } \\
\text { major coronary } \\
\text { events, } \\
\text { significant } \\
25 \% \text { reduction } \\
\text { in expanded } \\
\text { coronary } \\
\text { endpoint }\end{array}$ \\
\hline $\begin{array}{l}\text { LIPID } \\
\text { (1998) }\end{array}$ & $\begin{array}{l}\text { Pravastatin } \\
40 \mathrm{mg} \text { vs } \\
\text { placebo }\end{array}$ & 9,014 & $1,077(12 \%)$ & $\begin{array}{l}\text { No significant } \\
\text { reduction in } \\
\text { major coronary } \\
\text { events, } \\
\text { significant } \\
21 \% \text { reduction } \\
\text { in any } \\
\text { cardiovascular } \\
\text { event }\end{array}$ \\
\hline $\begin{array}{l}\text { HPS } \\
(2002)\end{array}$ & $\begin{array}{l}\text { Simvastatin } \\
40 \text { mg vs } \\
\text { usual care }\end{array}$ & 20,536 & $\begin{array}{l}5,963(28 \%), \\
3,051 \\
\text { secondary } \\
\text { prevention }\end{array}$ & $\begin{array}{l}\text { Significant } \\
\text { reduction in } \\
\text { defined } \\
\text { endpoint for } \\
\text { subcategories }\end{array}$ \\
\hline $\begin{array}{l}4 \mathrm{D} \\
(2005)\end{array}$ & $\begin{array}{l}\text { Atorvastatin } \\
20 \mathrm{mg} \text { vs } \\
\text { placebo }\end{array}$ & 1,255 & $1,255(100 \%)$ & $\begin{array}{l}\text { No significant } \\
\text { reduction in } \\
\text { MACE }\end{array}$ \\
\hline $\begin{array}{l}\text { SPARCL } \\
\text { (2006) }\end{array}$ & $\begin{array}{l}\text { Atorvastatin } \\
80 \mathrm{mg} \text { vs } \\
\text { placebo }\end{array}$ & 4,731 & $794(17 \%)$ & $\begin{array}{l}\text { No significant } \\
\text { reduction in } \\
\text { strokes, } \\
\text { significant } \\
\text { reduction in } \\
\text { major coronary } \\
\text { events and } \\
\text { MACE }\end{array}$ \\
\hline
\end{tabular}

a significant reduction in CHD events in the small subgroup of 202 with diabetes. ${ }^{14} \mathrm{~A}$ later post-hoc analysis was performed using newer diagnostic criteria for T2DM and confirmed a significant reduction in CHD events in 483 subjects with baseline diabetes..$^{15}$

The Cholesterol and Recurrent Events (CARE) trial was a secondary prevention study comparing pravastatin $40 \mathrm{mg}$ with placebo in 4,159 patients with a history of CHD and average cholesterol levels. ${ }^{16}$ The incidence of the primary endpoint of a fatal coronary event or non-fatal myocardial infarction was significantly reduced by $24 \%$ in the treatment group overall, demonstrating benefit of statin use in secondary prevention even in the absence of raised LDL cholesterol levels. In the 586 subjects with diabetes (14\%), the reduction in the primary endpoint was not significant but there was a $25 \%$ significant reduction in an expanded coronary endpoint. ${ }^{17}$

The Long-Term Intervention with Pravastatin in Ischaemic Disease (LIPID) trial involved a larger cohort of 9,014 patients with CHD, with 1,077 (12\%) diagnosed as having diabetes at baseline. ${ }^{18,19}$ Overall, pravastatin $40 \mathrm{mg}$ significantly reduced the primary outcome of mortality from CHD, and in a pre-specified subgroup analysis, pravastatin reduced the occurrence of major CHD events and major coronary events (CHD death or non-fatal myocardial infarction) in the subgroup with diabetes.

In the Heart Protection Study (HPS) 3,051 of the 5,963 subjects with diabetes $(51 \%)$ had prior CHD or other occlusive vascular disease. ${ }^{7}$ Simvastatin $40 \mathrm{mg}$ significantly reduced the rate of major vascular events in those with diabetes and prior CHD (from 38\% to $33 \%$ ) or other CVD (from $33 \%$ to $26 \%$ ).

A detailed description of evidence for the reduction of cardiovascular events with statins in the setting of diabetes and chronic kidney disease is beyond the scope of this review. A guideline for the management of lipids in adults with diabetes and/or chronic kidney disease was recently published in the British Journal of Diabetes and contains the evidence base for this treatment. ${ }^{20}$

The 4D study is worthy of mention, however, as it included only patients with T2DM on maintenance haemodialysis. ${ }^{21}$ Most of the patients in the 4D study had some form of vascular disease at baseline. No benefit on major adverse cardiovascular events (MACE) (cardiovascular death, myocardial infarction, stroke) was found comparing atorvastatin $20 \mathrm{mg}$ to placebo over the 4 years of the study. The authors postulated that initiating lipid-lowering therapy in this group of patients might be too late to observe beneficial effects. They also suggested that the pathogenesis of vascular events might be different in people with T2DM and nephropathy compared to people with T2DM and no renal complications. Additional factors in patients with renal failure such as sympathetic overactivity, left ventricular hypertrophy and cardiac fibrosis may contribute to CVD rather than the more traditional factors leading to atherosclerotic disease. A recent post-hoc analysis followed subjects up for a median of 11.5 years, and although MACE was not reduced, the risk of all cardiac events combined and the risk of cardiovascular death was significantly lower in the original atorvastatin group compared with the placebo group. 22

The Stroke Prevention by Aggressive Reduction in Cholesterol Levels (SPARCL) trial studied atorvastatin $80 \mathrm{mg}$ or placebo in 4,731 patients with recent stroke or transient ischaemic attack but no known coronary disease. ${ }^{23}$ Overall there was a significant reduction in further fatal or non-fatal strokes with atorvastatin. Subgroup analysis of 794 subjects (17\%) classified as having diabetes at baseline showed atorvastatin therapy did not significantly reduce the risk of further stroke, but did significantly reduce the risk of major coronary events, major cardiovascular events (MACE), any CHD event and revascularisation procedures. ${ }^{24}$

Thus, most studies have demonstrated significant benefits of statin therapy for secondary prevention of CVD in people with diabetes (Table 2). Guidelines reflect this by recommending statin 
therapy in the presence of prior atherosclerotic CVD, regardless of baseline LDL cholesterol concentrations or other cardiovascular risk factors.

\section{Evidence for benefits of high-dose versus low-dose statins in diabetes (Table 3 )}

Observational studies have shown a continuous positive relationship between LDL cholesterol concentrations and CVD. ${ }^{3}$ It follows that a greater reduction in LDL cholesterol might reduce the cardiovascular risk even further. A small number of studies, with mixed results, have compared high-dose versus low-dose statins to establish whether intensive lipid lowering improves cardiovascular outcomes, including substantial numbers of subjects with diabetes.

The Pravastatin or Atorvastatin Evaluation and Infection Therapy (PROVE IT) Thrombolysis in Myocardial Infarction (TIMI) 22 trial compared standard-dose pravastatin versus high-dose atorvastatin in people with recent acute coronary syndromes. ${ }^{25}$ High intensity statin treatment significantly reduced the primary extended cardio-

Table 3 Diabetes results from studies comparing low-dose and high-dose statins

\begin{tabular}{|c|c|c|c|c|}
\hline $\begin{array}{l}\text { Study } \\
\text { (year of } \\
\text { primary } \\
\text { publication) }\end{array}$ & Comparison & Subjects & $\begin{array}{l}\text { Subjects } \\
\text { with } \\
\text { diabetes (\%) }\end{array}$ & $\begin{array}{l}\text { Diabetes } \\
\text { results }\end{array}$ \\
\hline $\begin{array}{l}\text { PROVE IT } \\
(2004)\end{array}$ & $\begin{array}{l}\text { Atorvastatin } \\
80 \mathrm{mg} \text { vs } \\
\text { pravastatin } \\
40 \mathrm{mg}\end{array}$ & 4,162 & $978(23 \%)$ & $\begin{array}{l}\text { Significant } \\
25 \% \text { reduction } \\
\text { in acute } \\
\text { cardiac events }\end{array}$ \\
\hline $\begin{array}{l}\text { A to Z } \\
\text { (2004) }\end{array}$ & $\begin{array}{l}\text { Simvastatin } \\
40 \mathrm{mg} \text { then } \\
80 \mathrm{mg} \text { vs } \\
\text { placebo then } \\
\text { simvastatin } \\
20 \mathrm{mg}\end{array}$ & 4,497 & $1,059(24 \%)$ & $\begin{array}{l}\text { Insignificant } \\
\text { reduction } \\
\text { in primary } \\
\text { endpoint }\end{array}$ \\
\hline $\begin{array}{l}\text { TNT } \\
(2005)\end{array}$ & $\begin{array}{l}\text { Atorvastatin } \\
80 \mathrm{mg} \text { vs } \\
\text { atorvastatin } \\
10 \mathrm{mg}\end{array}$ & 10,001 & $1,501(15 \%)$ & $\begin{array}{l}\text { Significant } \\
25 \% \text { reduction } \\
\text { in major } \\
\text { cardiovascular } \\
\text { events }\end{array}$ \\
\hline $\begin{array}{l}\text { IDEAL } \\
(2005)\end{array}$ & $\begin{array}{l}\text { Atorvastatin } \\
80 \text { mg vs } \\
\text { simvastatin } \\
20-40 \text { mg }\end{array}$ & 8,888 & $1,069(12 \%)$ & $\begin{array}{l}\text { Overall no } \\
\text { significant } \\
\text { reduction in } \\
\text { primary } \\
\text { endpoint, } \\
\text { diabetes } \\
\text { subgroup not } \\
\text { reported }\end{array}$ \\
\hline $\begin{array}{l}\text { SEARCH } \\
(2010)\end{array}$ & $\begin{array}{l}\text { Simvastatin } \\
80 \text { mg vs } \\
\text { simvastatin } \\
20 \text { mg }\end{array}$ & 12,064 & $1,267(11 \%)$ & $\begin{array}{l}\text { Overall no } \\
\text { significant } \\
\text { reduction in } \\
\text { primary } \\
\text { endpoint, } \\
\text { diabetes } \\
\text { subgroup not } \\
\text { reported }\end{array}$ \\
\hline
\end{tabular}

vascular composite end point by $16 \%$ in the general study population. Nearly one quarter of the subjects in PROVE IT had diabetes and, although subgroup analysis showed a reduction in primary end points in the high intensity group, this did not reach statistical significance. ${ }^{26}$ The authors attributed this to the substudy being underpowered. A secondary 'triple' endpoint of acute cardiac events (death, myocardial infarction, unstable angina) was significantly reduced. A higher number of people in the intensive arm had abnormal liver function tests, but the rates of discontinuation of statin therapy due to side effects was not significantly different between groups.

The Treating to New Targets (TNT) study compared high-dose versus low-dose atorvastatin in 10,001 people with stable CHD. ${ }^{27}$ $1,501(15 \%)$ of the subjects had diabetes and subgroup analysis showed high-dose atorvastatin appeared to be beneficial in significantly reducing the risk of major cardiovascular events (CHD death, myocardial infarction, stroke, resuscitation after cardiac arrest) by $25 \% .{ }^{28}$ Safety analysis demonstrated a significantly greater number of adverse events in the intensively treated group, particularly an increase in abnormal liver function tests, with no significant differences between the rates of reported myalgia and rhabdomyolysis in both groups.

Three other studies comparing high-dose and low-dose statin therapy gave disappointing results..$^{29-31}$ The $A$ to $Z$ trial compared simvastatin $40 \mathrm{mg}$ then $80 \mathrm{mg}$ with placebo then simvastatin $20 \mathrm{mg}$ in 4,497 subjects following an acute coronary syndrome. ${ }^{29}$ 1,059 subjects had diabetes at baseline (24\%). There was a nonsignificant trend towards overall benefit in reducing the primary endpoint and also in subjects with diabetes, but this was not significant and the number of events was less than anticipated. The Incremental Decrease in End Points Through Aggressive Lipid Lowering (IDEAL) study compared atovastain $80 \mathrm{mg}$ with simvastatin $20 \mathrm{mg}$ in 8,888 subjects with a previous history of mycardial infarction, including 1,069 subjects with diabetes (12\%). ${ }^{30}$ The primary endpoint of major coronary events was not significatly reduced, but when the same endpoints as TNT or PROVE IT were examined, statisically significat reductions were observed. The Study of the Effectiveness of Additional Reductions in Cholesterol and Homocysteien (SEARCH) trial was even more disappointing, and an insignificant $6 \%$ reduction in major vascular events was observed comparing simvastatin $80 \mathrm{mg}$ with simvastain $20 \mathrm{mg}$ in 12,064 survivors of myocardial infarction, 1,267 of whom (11\%) had diabetes at baseline.

In summary, high intensity statin treatment, especially atorvastatin $80 \mathrm{mg}$, appeared to have some potential benefit in preventing further CVD in those with diabetes and atherosclerotic CVD. Intensive therapy was associated with greater side effects, particularly abnormal liver function tests.

\section{Meta-analysis of randomised controlled trials in people with diabetes}

There have been several meta-analyses of diabetes data from cardiovascular outcome trials of statins. By far the most important of these is the Cholesterol Treatment Trialists' (CTT) collaboration which used individual patient data rather than summary data. This 
collaboration was established before the results of any of these studies were available, and the first meta-analysis included individual patient data from 90,056 subjects in 14 randomised controlled trials of statin therapy. ${ }^{32}$ Studies that contributed to the metaanalysis comprised ALLHAT-LLT, ASCOT-LLA, CARDS, CARE, HPS, LIPID and $4 S$ trials, which are described above, plus three other studies of primary prevention (AFCAPS/TexCAPS, PROSPER, WOSCOPS), $33-35$ three secondary prevention studies (GISSI-P, LIPS, Post$(A B G)^{36-38}$ and one study in subjects post renal transplantation (ALERT). ${ }^{39} 18,686$ of the participants had diabetes, including 1,466 subjects with T1DM ( $2 \%$ of the total) and 17,220 with T2DM (19\% of the total). ${ }^{40}$ The results were strongly positive with a $9 \%$ reduction in all-cause mortality for every $1 \mathrm{mmol}$ reduction in LDL cholesterol with statins. This was irrespective of whether vascular disease was present prior to study recruitment (secondary prevention) or there was no known vascular disease (primary prevention). The proportional effect was similar in patients with T1DM and T2DM.

Back to back with the publication of the SEARCH trial, the Cholesterol Treatment Trialists' Collaboration produced a further metaanalysis of trials with at least 1,000 participants each with a follow-up duration of 2 years. ${ }^{41}$ They identified the five trials described earlier (A to Z, IDEAL, PROVE IT, SEARCH, TNT) and 21 trials of statins versus control. The results of intensive statin treatment were overwhelmingly positive and showed that more intensive lipid lowering led to a $15 \%$ further reduction in major vascular events compared with standard lipid lowering. Between $11 \%$ and $24 \%$ of people had diabetes in these five trials and the significant impact upon cardiovascular events was seen in both T1DM and T2DM. In terms of side effects of intensive therapy, only cases of rhabdomyolysis were investigated and these appeared to be related to the use of simvastatin $80 \mathrm{mg}$ daily.

Three other recent meta-analyses have been published, but these do not add new findings to the CTTC analyses. The first looked at data from seven randomised controlled trials of primary prevention (AFCAPS/TexCAPS, ASPEN, ASCOT-LLA, CARDS, HPS, MEGA, PROSPER) including 12,711 patients with diabetes. ${ }^{42}$ Statin therapy was associated with a significant $21 \%$ reduction in the incidence of cardiovascular events. No significant difference was found in all-cause mortality between statin-treated and control groups although all-cause mortality was only reported in three studies so this may have been underpowered for this outcome.

A further meta-analysis of 22 trials was conducted and found that statin therapy significantly reduced by $21 \%$ the incidence of CVD in subjects with diabetes. ${ }^{43}$ Finally, a recent meta-analysis included five studies of statin versus placebo (ASPEN, CARE, LIPID, HPS, 4S) and four studies of high-dose versus low-dose statins (A to Z, PROVE IT, SEARCH, TNT) and concluded that, compared with placebo, statin treatment reduced major cardiovascular or cerebrovascular events by $15 \%$ in subjects with diabetes, with a further $9 \%$ reduction comparing high-dose with low-dose statins. ${ }^{44}$

\section{Conclusion}

Statins are generally well tolerated and the risk of myopathy, myositis and rhabdomyolysis associated with statin use is rare. Statin ther-

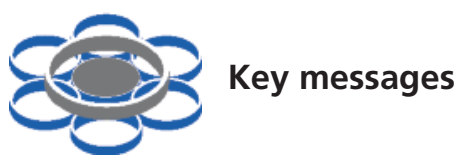

- Studies with statins in people with diabetes have shown significant reductions in cardiovascular events

- High-dose statins further reduce non-fatal events in people with established atherosclerotic disease

- Statins therapy should be considered in all people with diabetes over 40 years of age

apy slightly increases the development of new diabetes ${ }^{45}$ and this is more marked with higher dose statins. ${ }^{46}$ The metabolic side effects of statins in people with diabetes are a minor increase in $\mathrm{HbA}_{1 \mathrm{c}}$ of $1.3 \mathrm{mmol} / \mathrm{mol}(0.12 \%){ }^{47}$ but this is trivial compared with the overwhelming evidence of cardiovascular risk reduction. For primary prevention, most trials and meta-analyses have demonstrated a significant benefit of statin therapy in reducing cardiovascular events in those with diabetes. For secondary prevention, intensive lipid-lowering regimens with high-dose statins have an even greater benefit compared with standard lipid-lowering treatments in further reducing cardiovascular events, but higher doses may not be tolerated due to an increase in side effects.

Conflict of interest FN none declared. GMcK has received payment for advisory boards and/or lectures from MSD and Pfizer. MF has received payment for advisory boards and/or lectures from AstraZeneca, MSD and Pfizer

Funding None.

\section{References}

1. Verges B. Pathophysiology of diabetic dyslipidaemia: where are we? Diabetologia 2015;58:886-99.

http://dx.doi.org/10.1007/s00125-015-3525-8

2. Verges B. Lipid disorders in type 1 diabetes. Diabetes Metab 2009; 35:353-60. http://dx.doi.org/10.1016/j.diabet.2009.04.004

3. Emerging Risk Factors Collaboration. Diabetes mellitus, fasting blood glucose concentration, and risk of vascular disease: a collaborative metaanalysis of 102 prospective studies. Lancet 2010;375:2215-22. http://dx.doi.org/10.1016/S0140-6736(10)60484-9.

4. Colhoun HM, Betteridge DJ, Durrington PN, et al, on behalf of the CARDS Investigators. Primary prevention of cardiovascular disease with atorvastatin in type 2 diabetes in the Collaborative Atorvastatin Diabetes Study (CARDS): multicentre randomised placebo-controlled trial. Lancet 2004;364:685-96.

5. Knopp RH, d'Emden M, Smilde JG, Pocock SJ, on behalf of the ASPEN Study Group. Efficacy and safety of atorvastatin in the prevention of cardiovascular end points in subjects with type 2 diabetes: the Atorvastatin Study for Prevention of Coronary Heart Disease Endpoints in Noninsulin-dependent diabetes mellitus (ASPEN). Diabetes Care 2006;29: 1478-85. http://dx.doi.org/10.2337/dc05-2415

6. Heart Protection Study Collaborative Group. MRC/BHF Heart Protection Study of cholesterol-lowering with simvastatin in 20536 high-risk individuals: a randomised placebo-controlled trial. Lancet 2002;360:7-22.

7. Heart Protection Study Collaborative Group. MRC/BHF Heart Protection Study of cholesterol lowering with simvastatin in 5963 people with diabetes: a randomised placebo-controlled trial. Lancet 2003;361:200516.

8. ALLHAT Collaborative Research Group. Major outcomes in moderately hypercholesterolemic, hypertensive patients randomized to pravastatin 
vs usual care. The Antihypertensive and Lipid-Lowering Treatment to Prevent Heart Attack Trial (ALLHAT-LLA). JAMA 2002;288:2998-3007.

9. Sever PS, Dahlöf B, Poulter NR, et al, for the ASCOT Investigators. Prevention of coronary and stroke events with atorvastatin in hypertensive patients who have average or lower-than-average cholesterol concentrations, in the Anglo-Scandinavian Cardiac Outcomes Trial-Lipid-Lowering Arm (ASCOT-LLA): a multicentre randomised controlled trial. Lancet 2003:361:1149-58.

10. Sever PS, Poulter NR, Dahlöf B, et al, for the ASCOT Investigators. Reduction in cardiovascular events with atorvastatin in 2,532 patients with type 2 diabetes. Anglo-Scandinavian Cardiac Outcomes Trial-Lipid Lowering Arm (ASCOT-LLA). Diabetes Care 2005;28:1151-7.

11. Nakamura $\mathrm{H}$, Arakawa $\mathrm{K}$, Itakura $\mathrm{H}$, et al, for the MEGA Study Group. Primary prevention of cardiovascular disease with pravastatin in Japan (MEGA Study): a prospective randomised controlled trial. Lancet 2006; 368:1155-63. http://dx.doi.org/10.1016/S0140-6736(06)69472-5

12. Nishimura R, Sone $H$, Nakagami T, Tajima N. Importance of high-density lipoprotein cholesterol control during pravastatin treatment in hypercholesterolemic Japanese with type 2 diabetes: a post hoc analysis of MEGA study. Diabetes Res Clin Pract 2013;100:e31-3. http://dx.doi.org/10.1016/j.diabres.2013.02.003.

13. Scandinavian Simvastatin Survival Study Group. Randomised trial of cholesterol lowering in 4444 patients with coronary heart disease : the Scandinavian Simvastatin Survival Study (4S). Lancet 1994;344:13839.

14. Pyörälä K, Pedersen TR, Kjekshus J, Faergeman O, Olsson AG, Thorgeirsson $\mathrm{G}$. Cholesterol lowering with simvastatin improves prognosis of diabetic patients with coronary heart disease: a subgroup analysis of the Scandinavian Simvastatin Survival Study (4S). Diabetes Care 1997: 20:614-20.

15. Haffner SM, Alexander CM, Cook TJ, et al, for the Scandinavian Simvastatin Survival Study Group. Reduced coronary events in simvastatintreated patients with coronary heart disease and diabetes or impaired fasting glucose levels. Arch Intern Med 1999;159:2661-7.

16. Sacks FM, Pfeffer MA, Moye LA, et al, for the Cholesterol And Recurrent Events Trial Investigators. The effect of pravastatin on coronary events after myocardial infarction in patients with average cholesterol levels. $N$ Engl J Med 1996:335:1001-09.

17. Goldberg RB, Mellies MJ, Sacks FM, et al, for the CARE Investigators. Cardiovascular events and their reduction with pravastatin in diabetic and glucose intolerant myocardial infarction survivors with average cholesterol levels: subgroup analyses in the Cholesterol And Recurrent Events (CARE) trial. Circulation 1998;98:2513-19.

18. The Long-term Intervention with Pravastatin in Ischaemic Disease (LIPID) Study Group. Prevention of cardiovascular events and death with pravastatin in patients with coronary heart disease and a broad range of initial cholesterol levels. N Engl J Med 1998;339:1349-57.

19. Keech A, Colquhoun D, Best J, et al, for the LIPID Study Group. Secondary prevention of cardiovascular events with long-term pravastatin in patients with diabetes or impaired fasing glucose: results from the LIPID trial. Diabetes Care 2003;26:2713-21.

20. Mark PB, Winocour P, Day C. Management of lipids in adults with diabetes mellitus and nephropathy and/or chronic kidney disease: summary of joint guidance from the Association of British Clinical Diabetologists (ABCD) and the Renal Association (RA). Br J Diabetes 2017;17:64-72. http://dx.doi.org/10.15277/bjd.2017.125

21. Wanner C, Krane V, Marz W, et al, for the German Diabetes and Dialysis Study Investigators. Atorvastatin in patients with type 2 diabetes undergoing hemodialysis. N Engl J Med 2005;353:238-48. http://dx.doi.org/10.1056/NEJMoa043545

22. Krane V, Schmidt K-R, Gatjahr-Lengsfled $L$, et al, for the 4D study investigators (the German Diabetes and Dialysis Study investigators). Longterm effects following 4 years of randomized treatment with atorvastatin in patients with type 2 diabetes on hemodialysis. Kidney Int 2016;89:1380-7. http://dx. doi.org/10.1016/..kint.2015.12.033

23. The Stoke Prevention by Aggressive Reduction in Cholesterol Levels (SPARCL) Investigators. High-dose atorvastatin after stroke or transient ischemic attack. N Engl J Med 2006;355:549-59.

24. Callahan A, Amerenco P, Goldstein LB, et al, for the SPARCL Investigators. Risk of stroke and cardiovascular events after ischemic stroke or transient ischemic attack in patients with type 2 diabetes or metabolic syndrome. Arch Neurol 2011;68:1245-51.

http://dx.doi.org/10.1001/archneurol.2011.146

25. Cannon CP, Braunwald E, McCabe $\mathrm{CH}$, et al, for the Pravastatin or Atorvastatin Evaluation and Infection Therapy-Thrombolysis in Myocardial Infarction 22 Investigators. Intensive versus conventional lipid lowering with statins after acute coronary syndromes. N Engl J Med 2004; 350:1495-504. http://dx.doi.org/10.1056/NEJMoa040583

26. Ahmed S, Cannon CP, Murphy SA, Braunwald E. Acute coronary syndromes and diabetes: is intensive lipid lowering beneficial? Results of PROVE IT-TIMI 22. Eur Heart J 2006:27:2323-9.

http://dx.doi.org/10.1093/eurheartj/ehl220

27. LaRosa JC, Grundy SM, Waters DD, et al. for the Treating to New Targets (TNT) Investigators. Intensive lipid lowering with atorvastatin in patients with stable coronary disease. N Engl J Med 2005;352:1425-35. http://dx.doi.org/10.1056/NEJMoa050461

28. Shepherd J, Barter P, Carmena R, et al, for the Treating to New Targets Investigators. Effect of lowering LDL cholesterol substantially below currently recommended levels in patients with coronary heart disease and diabetes: the Treating To New Targets (TNT) study. Diabetes Care 2006:29:1220-6. http://dx. doi.org/10.2337/dc05-2465

29. de Lemos JA, Blazing MA, Wiviott SD, et al, for the A to $Z$ Investigators Early intensive vs delayed conservative simvastatin strategy in patients with acute conronary syndromes: phase $Z$ of the $A$ to $Z$ trial. JAMA 2004:292:1307-16.

30. Pedersen TR, Faergeman O, Kastelein JJP, et al, for the Incremental Decrease in End Points Through Aggressive Lipid Lowering (IDEAL) Study Group. High-dose atorvastatin vs usual-dose simvastatin for secondary prevention after myocardial infarction. The IDEAL study: a randmized controlled trial. JAMA 2005;294:2437-45.

31. Study of the Effectiveness of Additional Reductions in Cholesterol and Homocysteine (SEARCH) Collaborative Group. Intensive lowering of LDL cholesterol with $80 \mathrm{mg}$ versus $20 \mathrm{mg}$ simvastatin daily in 12064 survivors of myocardial infarction: a double-blind randomised trial. Lancet 2010;376:1658-69. http://dx.doi.org/10.1016/S0140-6736(10)60310-8.

32. Cholesterol Treatment Trialists' (CTT) Collaborators. Efficacy and safety of cholesterol-lowering treatment: prospective meta-analysis of data from 90056 participants in 14 randomised trials of statins. Lancet 2005; 366:1267-78. http://dx.doi.org/10.1016/S0140-6736(05)67394-1

33. Downs JR, Clearfield M, Weis $\mathrm{S}$, et al, for the AFCAPS/TexCAPS Research Group. Primary prevention of acute coronary events with lovastatin in men with average cholesterol levels: results of AFCAPS/TexCAPS. JAMA 1998;279:1615-22.

34. Shepherd J, Blauw GJ, Murphy MB, et al, on behalf of the PROSPER Study Group. Pravastatin in elderly individuals at risk of vascular disease (PROSPER): a randomised controlled trial. Lancet 2002;360:1623-30.

35. Shepherd J, Cobbe CM, Ford I, et al, for the West of Scotland Coronary Prevention Study Group. Prevention of coronary heart disease with pravastatin in men with hypercholesterolemia. N Engl J Med 1995; 333:1301-07.

36. GISSI Prevenzione Investigators. Results of the low-dose $(20 \mathrm{mg})$ pravastain GISSI Prevenzione trial in 4271 patients with recent myocardial infarction: do stopped trials contribute to overall knowledge? Ital Heart J 2000:1:810-20.

37. Serruys PW, de Feyter P, Macaya C, et al, for the Lescol Intervention Prevention Study (LIPS) Investigators. Fluvastatin for prevention of cardiac events following successful first percutaneous coronary intervention: a randomized controlled trial. JAMA 2002;287:3215-22.

38. The Post Coronary Artery Bypass Graft Trial Investigators. The effect of aggressive lowering of low-density lipoprotein cholesterol levels and low-dose anticoagulation on obstructive changes in saphenous-vein coronary bypass grafts. N Engl J Med 1997;336:153-62

39. Holdaas $H$, Fellstrom B, Jardine AJ, et al, on behalf of the Assessment of Lescol in Renal Trnasplantation (ALERT) Study Investigators. Effect of fluvastatin on cardiac outcomes in renal transplant receipients: a multicentre, randomised, placebo-controlled trial. Lancet 2003;361:202431. http://dx. doi.org/10.1016/S0140-6736(03)13638-0

40. Cholesterol Treatment Trialists' (CTT) Collaborators. Efficacy of cholesterol-lowering therapy in 18686 people with diabetes in 14 randomised trials of statins: a meta-analysis. Lancet 2008;371:117-25. 
http://dx.doi.org/10.1016/S0140-6736(08)60104-X

41. Cholesterol Treatment Trialists' (CTT) Collaboration. Efficacy and safety of more intensive lowering of LDL cholesterol: a meta-analysis of data from 170000 participants in 26 randomised trials. Lancet 2010;376: 1670-81. http://dx.doi.org/10.1016/S0140-6736(10)61350-5

42. Chen Y-H, Feng B, Chen Z-W. Statins for primary prevention of cardiovascular and cerebrovascular events in diabetic patients without established cardiovascular disease: a meta-analysis. Exp Clin Endocrinol Diabetes 2012;120:116-20. http://dx.doi.org/10.1055/s-0031-1297968

43. Chang $Y-H$, Hsieh M-C, Wang C-Y, Lin K-C, Lee $Y$-J. Reassessing the benefits of statins in the prevention of cardiovascular disease in diabetic patients: a systemetic review and meta-analysis. Rev Diabet Studies 2013;10:157-70. http://dx.doi.org/10.1900/RDS.2013.10.157

44. de Vries FM, Kolthof J, Postma MJ, Denig P, Hak E. Efficacy of standard and intensive statin treatment for the secondary prevention of cardiovascular and cerebrovascular events in diabetes patients: a meta-analysis. Plos One 2014;9:e111247.

http://dx.doi.org/10.1371/journal.pone.0111247

45. Sattar N, Preiss D, Murray HM, et al. Statins and risk of incident diabetes: a collaborative meta-analysis of randomised statin trials. Lancet 2010;375:735-42. http://dx.doi.org/10.1016/S0140-6736(09)61965-6

46. Preiss $D$, Seshasai SR, Welsh $P$, et al. Risk of incident diabetes with intensive-dose compared with moderate-dose statin therapy: a metaanalysis. JAMA 2011;305:2556-64. http://dx.doi.org/10.1001/jama.2011.860

47. Erqou S, Lee CC, Adler Al. Statins and glycaemic control in individuals with diabetes: a systematic review and meta-analysis. Diabetologia 2014;57:2444-52. http://dx.doi.org/10.1007/s00125-014-3374-x. 